\title{
Application Education as a Place to Increase Community Income During the Covid-19 Pandemic in Parungponteng
}

\author{
Renda Sandi Saputra \\ Department of Computer Sciences, Universitas Informatika dan Bisnis Indonesia, Bandung, Indonesia \\ Corresponding author mail: rendasandi8888@gmail.com
}

\begin{abstract}
Blood clams (Anadara granosa) are endemic clams found in Southeast Asia and East Asia. Blood clams are widely consumed by the public as seafood dishes in coastal food stalls. The great potential of blood clams will increase the waste of clam shells produced. The accumulation of shellfish waste will cause pollution and reduce environmental aesthetics. The chitin content in blood clam shells can be used as chitosan. Chitosan is a polymer of -(1-4) glucosamine which is formed when the acetyl group in chitin is substituted by hydrogen to become an amine group. Chitosan has antibacterial and antifungal properties. Isolation of chitosan was carried out through the stages of demineralization, deproteination, and deacetylation. The limited use of laboratories during the pandemic is a major obstacle in the isolation process of chitosan. This study aims to process blood clam shell waste into chitosan in a simple way on a home scale. Processing includes deproteination, demineralization, and deacetylation were done using tools and materials available at home. Laboratory equipment such as beakers could be replaced with pots, the reflux process was replaced by using a cloth to filter, and measuring cups were replaced with glasses. The research used 1500 grams of blood clam shell powder and produced 1050 grams of white chitosan with a slightly hard texture.
\end{abstract}

Keywords: Introduction of money-making applications in the community

\section{Introduction}

During the pandemic, the limited use of laboratories became the main obstacle in the chitosan isolation process (Novika and Meliyani, 2021). This is because the isolation process requires tools and materials available in the laboratory. Based on these problems, this study aims to process blood clam shell waste into simple chitosan on a home scale. The process carried out in the research is a process of modification and innovation by utilizing simple equipment and is expected to help provide a reference for making chitosan independently.

The development of technology has a positive impact on the people of Parungponteng, especially in the midst of the Covid-19 pandemic which requires us to carry out activities at home, one of the developments is that people can earn income easily by using gadgets. This development has its own impact on the economy and people's lifestyles (Kaye et al., 2021; Andriyani et al., 2021; Suyatna, 2021). According to the Financial Services Authority (OJK), fintech is an innovation in the financial services industry that utilizes the use of technology. Fintech products are usually in the form of a system built to carry out specific financial transaction mechanisms. Innovation in fintech is a company engaged in financial services that uses technology to accelerate and facilitate aspects of the financial services it provides (Leong and Sung, 2018; Au and Kauffman, 2008; Leaven et al., 2015; Marzuki and Nurdin, 2020).

The snack video application has been widely used in other areas, not only among adults or employees but also widely used among students, using the application from this video snack can provide income to buy goods that are a need or desire for its users, such as electronic needs, fashion and the others (Alghofiki, 2021). Getting money from this application can be easily done by all people by participating in events provided by the application, such as watching videos, becoming content creators and inviting users who have never used this video snack application (Duscher et al., 2013; Islam et al., 2010; Mustafa et al., 2019).

The income from this application is no joke, starting from IDR 8,000 a day to IDR. 1,000,000 a day, by looking at the nominal amount, it certainly has a positive impact on the people of Parungponteng who do not earn enough from their main job. the public can receive money from the application after running the event, which is $1 \times 24$ hours. To exchange coins after getting a bonus from inviting new users at 01:00 PM and automatically converting them into cash, the user can withdraw the money using ewalet such as OVO, DANA, GOPAY and SHOPEEPAY (Ferdiana and Darma, 2019; Danuarta and Darma, 2019; Raharja et al., 2020; Novika et al., 2021). 

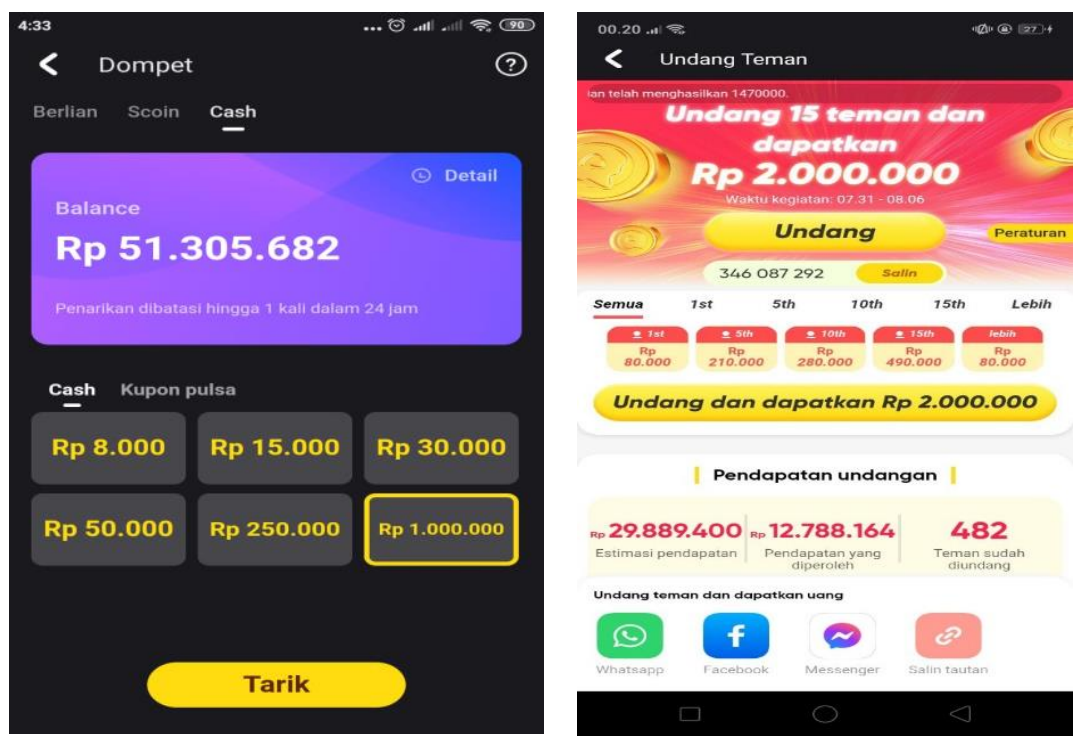

Figure 1. Daily withdrawals from the app

The Snack Video application was stopped operating by (OJK), Chairman of the Investment Alert Task Force (SWI) Tongam L Tobing said the factor that made Snack Video illegal was that the application was not registered with the Communications and Information Technology (See Figure 1). information system operator at the Ministry of Communication and Informatics and there is no license for business activities in Indonesia. This application has been accessed again and is declared legal and fulfills all the required permits. The video snack has met the permit for activities in Indonesia, said the Chairman of the Investment Alert Task Force (SWI). In addition to having been declared legal and meeting permits, Tongam also said that the Snack Video application has received an Electronic System Operator (PSE) from the Ministry of Communication and Information. Based on the Kominfo PSE list, Snack Video is registered with an electronic system with registration number 000251.01/DJAI.PSE/03/2021 on March 4, 2021, with the address snackvideo.com. Snack Video through the application has also sent notifications to users, that Snack Video can be used normally.

\section{Methodology}

The implementation of the service activity took place on April 15, 2021 in the vicinity of Parungponteng Square, RT 01 RW 01, Parungponteng Village, Tasikmalaya Regency (See Figure 2). The target of this community service program is parents who have and do not have a steady income.
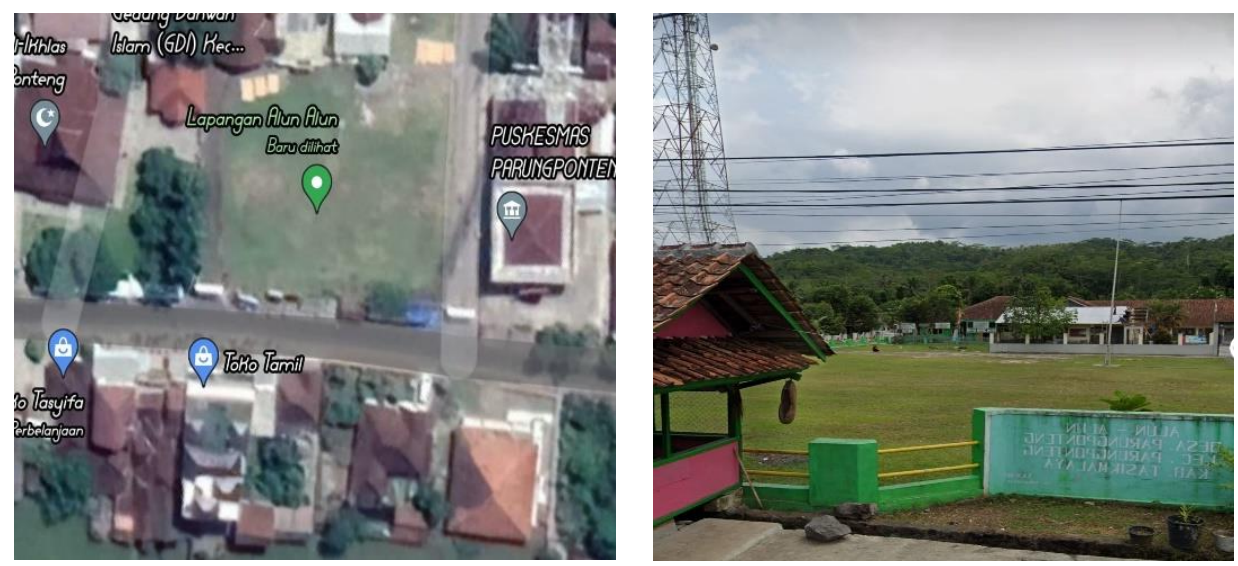

Figure 2. The research location is in the village square of Parungponteng

The method used in the implementation of this activity is socialization with counseling techniques in the form of lectures or explaining the benefits of money-making applications in the form of theories and animated videos related to practice. 
- observation stage

This activity was carried out as an initial activity with the aim of helping the community's economy amidst the COVID-19 pandemic

- socialization stage

In this stage, the verbal method uses word of mouth by using animated videos so that the explanations received by the community are clearly and easily understood.

- Extension Implementation Stage

The implementation of this activity for the community is carried out in collaboration with the chairman of the surrounding community. In this counseling, the community will be given an explanation about how to have additional income or a side job from the video snack application, which is very helpful for the economy during the COVID-19 pandemic.

\section{Results and Discussion}

The team carried out these activities while still carrying out the Covid-19 health protocol recommended by the government, namely by wearing masks, washing hands and maintaining distance. Before starting our activities, we conducted a Covid 19 Health Protocol Check and Participant Registration. This outreach activity began with remarks from the local community leader, followed by material presentation and question and answer discussion with the community. The resource person from the team, namely Muhammad Idris conveyed material on technology development, and the rest of the team presented material on how to use the video snack application, starting from how to install the video snack application, create an email, register in the snack video application and how to participate in events. Here the team also provides ways to invite friends or relatives to how to withdraw money from using the application to an ewalet or to an ATM (See Figure 3).

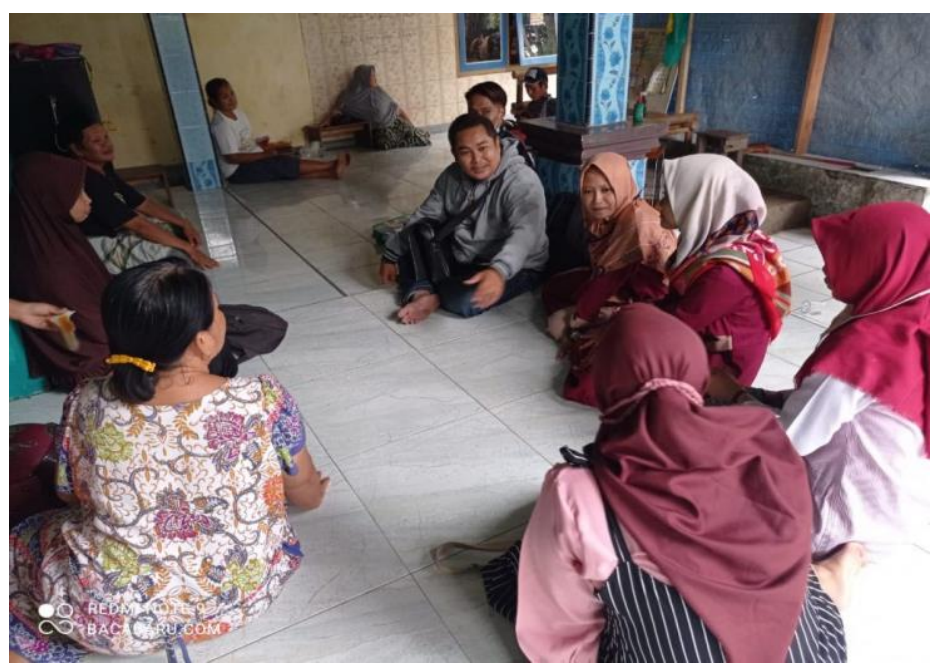

Figure 3. delivery of material carried out by the team

In addition to getting additional income from this meeting for the community, the people of Parungponteng can also know the importance of the internet for daily life such as in the health sector, in the economic field, and in business. Fundamentally, internet facilities have changed the market paradigm. Starting from the promotion of goods to marketing and ordering that can be accessed directly. Banking, stock transactions, publishing, and advertising are also carried out via the Internet. Buying and selling transactions can be done to increase people's income through the internet network, because it can be used as a very effective and efficient online business media because of the speed of access and cost-effectiveness.

\section{Conclusions}

Based on the results of the discussion, it can be concluded that the existence of Financial Technology (Fintech) has a positive impact during the covid-19 pandemic, it is hoped that it can synergize with the financial and banking services industry. The hope is that both parties can develop together by increasing access to financial services for the people of Parungponteng. 


\section{References}

Alghofiki, M. L. (2021, December). Legal Protection Against Song Covers in Snack Video Applications Judging from Law Number 28 of 2014 concerning Copyrights. In Journal Universitas Muhammadiyah Gresik Engineering, Social Science, and Health International Conference (UMGESHIC) (Vol. 1, No. 2, pp. 429-441).

Andriyani, D., Nailufar, F., Yurina, Y., Ratna, R., \& Rahmah, M. (2021). Analyzing the Sustainability of Micro, Small and Medium Enterprises during Covid-19 Pandemic in Bireuen Regency, Indonesia. International Journal of Business, Economics, and Social Development, 2(3), 119-126.

Au, Y. A., \& Kauffman, R. J. (2008). The economics of mobile payments: Understanding stakeholder issues for an emerging financial technology application. Electronic commerce research and applications, 7(2), 141-164.

Danuarta, G. L. N., \& Darma, G. S. (2019). Determinants of Using Go-Pay and Its Impact on Net Benefits. International Journal of Innovative Science and Research Technology, 4(11), 173-182.

Duscher, D., Apfolterer, S., Gärner, S., Worseg, A., \& Bartsch, R. (2013). Time is money: a faster way of Steri-Strip application (the 3-finger technique). Aesthetic surgery journal, 33(6), 924-925.

Ferdiana, A. M. K., \& Darma, G. S. (2019). Understanding Fintech Through Go-Pay. International Journal of Innovative Science and Research Technology, 4(2), 257-260.

Islam, R., Islam, R., \& Mazumder, T. (2010). Mobile application and its global impact. International Journal of Engineering \& Technology (IJEST), 10(6), 72-78.

Kaye, A. D., Okeagu, C. N., Pham, A. D., Silva, R. A., Hurley, J. J., Arron, B. L., ... \& Cornett, E. M. (2021). Economic impact of COVID-19 pandemic on healthcare facilities and systems: International perspectives. Best Practice \& Research Clinical Anaesthesiology, 35(3), 293-306.

Laeven, L., Levine, R., \& Michalopoulos, S. (2015). Financial innovation and endogenous growth. Journal of Financial Intermediation, 24(1), 1-24.

Leong, K., \& Sung, A. (2018). FinTech (Financial Technology): what is it and how to use technologies to create business value in fintech way?. International Journal of Innovation, Management and Technology, 9(2), 74-78.

Marzuki, M., \& Nurdin, N. (2020). The influence of halal product expectation, social environment, and fiqih knowledge on intention to use shariah financial technology products. International Journal of Innovation, Creativity and Change, 13(1), 171-193.

Mustafa, M., Mazhar, N., Asghar, A., Usmani, M. Z., Razaq, L., \& Anderson, R. (2019, May). Digital Financial Needs of Microentrepreneur Women in Pakistan: Is Mobile Money the Answer?. In Proceedings of the 2019 CHI Conference on Human Factors in Computing Systems (pp. 1-12).

Novika, F., Halim, R. D., \& Setyawan, A. B. (2021). The Effect of Technological and Behavioral on the Adoption of the Shopeepay Mobile Payment. Journal of Entrepreneurship \& Business, 2(2), 106-118.

Novika, F., \& Meliyani, R. (2021). Procrustes Analysis of Indonesian Mortality Table Iv and Indonesia's Death Rate During Covid-19 Pandemic. International Journal of Quantitative Research and Modeling, 2(2), 91-96.

Suyatna, N. (2021). The Effect of Stimulus Policies and Risk-Based Capital Levels on Solvency at PT. Indonesian Takaful using Sharia Principles during the Majeur Force Period (Covid-19 Pandemic) in Indonesia. International Journal of Business, Economics, and Social Development, 2(1), 24-31. 